\title{
Chemical composition and fermentation characteristics of feedstuffs for giraffes (Giraffa camelopardalis) in German zoos
}

\author{
I. Gussek ${ }^{1}$, C. Große-Brinkhaus', J. Hummel² and K.-H. Südekum ${ }^{1,3}$ \\ ${ }^{1}$ University of Bonn, Institute of Animal Science \\ Endenicher Allee 15, 53115 Bonn, Germany \\ 2 University of Göttingen, Department of Animal Sciences \\ Kellnerweg 6, 37077 Göttingen, Germany
}

KEY WORDS: giraffe, metabolizable energy, gas production, browse, forage, lucerne hay, sugar beet pulp
Received: 18 October 2015

Revised: 23 February 2016

Accepted: $\quad 20$ May 2016
${ }^{3}$ Corresponding author:

e-mail: ksue@itw.uni-bonn.de

\begin{abstract}
The aim of the study was to evaluate the nutritive value of feedstuffs for giraffes in zoos. In total, 196 samples of six categories of forage $(n=111)$ and eight categories of non-forage feedstuffs $(n=85)$ were analysed for chemical composition and in vitro gas production (GP). Lucerne hay as main forage source showed a stable average quality (mean \pm standard deviation: crude protein $179 \pm 19 \mathrm{~g} \cdot \mathrm{kg}^{-1}$ dry matter (DM); metabolizable energy $8.9 \pm 0.6 \mathrm{MJ} \cdot \mathrm{kg}^{-1} \mathrm{DM}$ ) and its fibre fraction content was the most similar to browse leaves. Depending on the type, browse showed large variation in composition and fermentation. Supplementation of polyethylene glycol as tannin-binding agent, led to a significant increase of GP in leaves and bark. According to application, non-forage feeds differed in energy and crude protein contents, and fibre fractions. The chemical composition and GP of dehydrated lucerne pellets were very similar to lucerne hay, whereas other compound feeds were balanced. Characteristics of sugar beet pulp would ensure a beneficial fermentation when compared to other high-energy feedstuffs. A dietary substitution of fruits and vegetables with sugar beet pulp led to less distinct peaks in the theoretical GP of whole rations over $24 \mathrm{~h}$. Available nutritive recommendations for giraffes in captivity were generally confirmed; however, the protein delivering capacity of lucerne hay was suspected to be undervalued. Comprehensive analyses of leaves and bark resulted in additional information on temperate browse.
\end{abstract}

\section{Introduction}

In accordance with their classification as purely browsing, but comparatively little selective ruminants (Van Soest, 1988; Steuer et al., 2014), giraffes (Giraffa camelopardalis) forage efficiently for Acacia sp. under natural conditions (Pellew, 1984). In a zoo environment foraging is less complex (Baer et al.,
1985). Access to browse is limited due to seasonal restrictions or rather individual zoo management, so physically effective fibre and nutrients should be supplied with alternative feedstuffs. In such a forage, the chemical and structural composition of cell walls should resemble browse (Robbins and Moen, 1975; Hummel et al., 2006a), which widely applies to lucerne hay (Lagowski et al., 1958). 
Furthermore, lucerne hay guarantees high forage intake in ruminants (Thornton and Minson, 1973) and is steadily available in a comparably consistent quality. Nevertheless, Hatt et al. (2005) showed that lucerne hay as sole feedstuff does not meet the energy requirements of giraffes. Some kind of non-forage components should be supplemented to giraffe diets not exceeding $50 \%$ of daily dry matter (DM) intake (Hummel et al., 2006b). Thereby the fermentative behaviour of non-forage feedstuffs should be considered, as excessive amounts of energy providing ingredients, like starch and sugar, can lead to nonphysiological conditions in the rumen (Van Soest et al., 1991). The available catalogue of established concentrate feedstuffs for giraffes (Hummel and Clauss, 2006) shows that most pelleted compound feeds and dehydrated lucerne pellets sufficiently meet the energy requirements and at the same time are safe and consistent. This also applies to unmolassed sugar beet pulp used as energy concentrate, known for its beneficial fermentation characteristics, despite its high energy content (Van Soest et al., 1991).

With regard to chemical composition and fermentation characteristics, the aim of the present study was 1 . to evaluate the quality of lucerne hay as prevailing forage source for giraffes and its resemblance to browse and 2. to approve recommendations on suitable feeds for captive giraffes concerning their composition and fermentative characteristics.

\section{Material and methods}

\section{Sample collection}

In total, 196 feed samples were taken during 18 feed intake periods in the giraffe facilities of twelve German zoos located in Dortmund, Dresden, Duisburg, Frankfurt on the Main, Gelsenkirchen, Hanover, Cologne, Munster, Neunkirchen (Saar), Nuremberg, Schwerin and Stuttgart. Feed samples were divided into forage $(\mathrm{n}=111)$ with browse leaves and bark (temperate types), dried browse (types of berry and Acacia sp.), lucerne hay, lucerne-grass-mixtures and other forage, and non-forage $(\mathrm{n}=85)$ with pelleted compound feed, dehydrated lucerne pellets, pelleted browse-based product, sugar beet pulp, soyabean meal (solvent-extracted), energy- and fibre-rich cereal grain products, and fruits and vegetables (produce). Single grass hay and grass-clover hay samples were examined separately (Table 1).

\section{General analyses}

The samples were milled through $1 \mathrm{~mm}$ pore size sieves (forage: cutting mill SM 100, Retsch GmbH \& Co. KG, Haan, Germany; others: cen-
Table 1. Categories of forage and non-forage feeds and number of samples collected during documentation periods in giraffe facilities of twelve German zoos

\begin{tabular}{lr}
\hline Feedstuff & $\begin{array}{c}\text { No.of collected and } \\
\text { analysed samples }\end{array}$ \\
\hline Forage & \\
browse leaves & 42 \\
browse bark & 35 \\
dried browse & 5 \\
lucerne hay & 19 \\
lucerne-grass mixture & 5 \\
other forage & 3 \\
$\quad$ nettle & \\
$\quad$ erusalem artichoke (overground part) & \\
grass-clover hay & $1^{*}$ \\
grass hay & $1^{*}$ \\
Non-forage & \\
compound feed & 16 \\
dehydrated lucerne pellets & 10 \\
pelleted browse-based product & 3 \\
sugar beet pulp & 9 \\
soyabean meal (solvent-extracted) & 6 \\
energy-rich cereal grain products & 11 \\
$\quad$ oat flakes & \\
wheat flakes & \\
maize grain & \\
$\quad$ crispbread & \\
rice & \\
fibre-rich cereal grain products & \\
produce & \\
$\quad$ mixtures of fruits and vegetables & \\
$\quad$ potatoes & \\
\hline
\end{tabular}

*excluded from statistical analyses (single samples only)

trifugal mill Retsch ZM 200, Retsch GmbH \& Co. KG, Haan, Germany). Moist feeds were freezedried before milling (Model P18K-E, Piatkowski Fors-chungsgeräte, München, Germany). All proximate analyses were done according to VDLUFA methods (2012). The dry matter (DM) was determined by oven-drying of duplicate subsamples at $105^{\circ} \mathrm{C}$ (method 3.1). Ash and crude fat (CF) were analysed using methods 8.1 and 5.1.1. Crude protein (CP) was determined by Dumas combustion (method 4.1.2, Rapid N Cube, Elementar Analysesysteme $\mathrm{GmbH}$, Hanau, Germany). Crude fibre was analysed according to method 6.1.1. 'Ash-free' neutral deter-gent fibre (aNDFom, method 6.5.1; assayed with heat stable amylase, expressed exclusive of residual ash), 'ash-free' acid detergent fibre (ADFom, method 6.5.2; expressed exclusive of residual ash) and acid detergent lignin (ADL; method 6.5.3) were analysed using the Ankom A2000I Fiber analyzer system (Ankom Technology, Macedon, USA). 
In accordance with method 6.5.2, point 8.8, the analysis of ADFom was done sequentially for lucerne products, beet pulp and produce as for pectin-containing feedstuffs. Starch was estimated enzymatically employing a heat-stable $\alpha$-amylase (Termamyl 120 L; Novo Industrials, Bagsværd, Denmark) as a starch solubilizing agent (Brandt et al., 1987).

\section{In vitro gas production}

The Hohenheim gas test (method 25.1) was conducted to measure the $24 \mathrm{~h}$ in vitro gas production (GP) needed for estimation of metabolizable energy (ME) content, and to measure GP over $96 \mathrm{~h}$ (at 2, 4, $8,12,24,32,48,56,72,80$ and 96 h of incubation). To consider the effects of tannins on browse fermentation, the leaf and bark samples were incubated with or without polyethylene glycol (PEG) 6000 a substance having high affinity and capability to inert tannins (Makkar et al., 1995).

\section{Calculations}

The ME content was calculated using best fitting equations for the feed type:

1. lucerne hay

$\mathrm{ME}\left(\mathrm{MJ} \cdot \mathrm{kg}^{-1} \mathrm{DM}\right)=11.63+0.04837 \times \mathrm{GP}$ $\left(\mathrm{ml} \cdot 200 \mathrm{mg}^{-1} \mathrm{DM}\right)-0.01256 \times \mathrm{ash}\left(\mathrm{g} \cdot \mathrm{kg}^{-1} \mathrm{DM}\right)$ $-0.01228 \times$ crude fibre $\left(\mathrm{g} \cdot \mathrm{kg}^{-1} \mathrm{DM}\right)+0.01435$

$\times$ CF $\left(\mathrm{g} \cdot \mathrm{kg}^{-1} \mathrm{DM}\right)$; (Losand et al., 2014),

2. lucerne-grass-mixtures, grass hay and grassclover hay

ME $\left(\mathrm{MJ} \cdot \mathrm{kg}^{-1} \mathrm{DM}\right)=7.81+0.07559 \times \mathrm{GP}$ $\left(\mathrm{ml} \cdot 200 \mathrm{mg}^{-1} \mathrm{DM}\right)-0.00384 \times \mathrm{ash}\left(\mathrm{g} \cdot \mathrm{kg}^{-1} \mathrm{DM}\right)$ $+0.00565 \times \mathrm{CP}\left(\mathrm{g} \cdot \mathrm{kg}^{-1} \mathrm{DM}\right)+0.01898 \times \mathrm{CF}$ $\left(\mathrm{g} \cdot \mathrm{kg}^{-1} \mathrm{DM}\right)-0.00831 \times$ ADFom $\left(\mathrm{g} \cdot \mathrm{kg}^{-1} \mathrm{DM}\right)$; (GfE, 2008),

3. browse, dehydrated lucerne pellets and further forage

$\mathrm{ME}\left(\mathrm{MJ} \cdot \mathrm{kg}^{-1} \mathrm{DM}\right)=2.20+0.1357 \times \mathrm{GP}$ $\left(\mathrm{ml} \cdot 200 \mathrm{mg}^{-1} \mathrm{DM}\right)+0.0057 \times \mathrm{CP}\left(\mathrm{g} \cdot \mathrm{kg}^{-1} \mathrm{DM}\right)$ $+0.0002859 \times \mathrm{CF}^{2}\left(\mathrm{~g} \cdot \mathrm{kg}^{-1} \mathrm{DM}\right)$; (Menke and Steingass, 1988),

4. compound feed and pelleted browse-based product $\operatorname{ME}\left(\mathrm{MJ} \cdot \mathrm{kg}^{-1} \mathrm{DM}\right)=7.17+0.06463 \times \mathrm{GP}$ $\left(\mathrm{ml} \cdot 200 \mathrm{mg}^{-1} \mathrm{DM}\right)-0.01171 \times \mathrm{ash}\left(\mathrm{g} \cdot \mathrm{kg}^{-1} \mathrm{DM}\right)$ $+0.00712 \times \mathrm{CP}\left(\mathrm{g} \cdot \mathrm{kg}^{-1} \mathrm{DM}\right)+0.01657 \times \mathrm{CF}$ $\left(\mathrm{g} \cdot \mathrm{kg}^{-1} \mathrm{DM}\right)+0.00200 \times \operatorname{starch}\left(\mathrm{g} \cdot \mathrm{kg}^{-1} \mathrm{DM}\right)$ $-0.00202 \times \operatorname{ADFom}\left(\mathrm{g} \cdot \mathrm{kg}^{-1} \mathrm{DM}\right) ;(\mathrm{GfE}, 2009)$,

5 . sugar beet pulp, soyabean meal, energy-rich cereal grain products, fibre-rich cereal grain pro-ducts and produce

$\mathrm{ME}\left(\mathrm{MJ} \cdot \mathrm{kg}^{-1} \mathrm{DM}\right)=1.06+0.1570 \times \mathrm{GP}$ $\left(\mathrm{ml} \cdot 200 \mathrm{mg}^{-1} \mathrm{DM}\right)+0.0084 \times \mathrm{CP}\left(\mathrm{g} \cdot \mathrm{kg}^{-1} \mathrm{DM}\right)$ $+0.0220 \times \mathrm{CF}\left(\mathrm{g} \cdot \mathrm{kg}^{-1} \mathrm{DM}\right)-0.0081 \times$ ash $\left(\mathrm{g} \cdot \mathrm{kg}^{-1} \mathrm{DM}\right)$; (Menke and Steingass, 1988).
In order to study GP from tannin-containing forage under in vitro conditions, the ME was calculated as average $24 \mathrm{~h}$ GP during incubation with or without PEG.

The method by Ørskov and McDonald (1979) was used to estimate the fermentation parameters and was performed via non-linear regression in software programme GraphPad PRISM 5 for Windows (GraphPad PRISM Software, Inc., La Jolla, CA, USA) using the equation:

$$
\mathrm{y}=\mathrm{a}+\mathrm{b}\left(1-\mathrm{e}^{-\mathrm{ct}}\right)
$$

where: $y$ - cumulative GP at point $t, a-$ initial GP of soluble ingredients in the inoculum, $b$ - potential GP of insoluble, fermentable ingredients in the inoculum, $c-$ GP rate, $a+b-$ maximum GP.

Short time GP was specified as cumulative GP at two hours of incubation (GP2).

Theoretical $24 \mathrm{~h}$ GP distribution was plotted depending on differently composed non-forage portions of $5 \mathrm{~kg} \mathrm{DM}$ (representing $50 \%$ of total daily DM intake) and $4 \% \cdot \mathrm{h}^{-1}$ passage rate of particles. The nonforage portion was either based on $50 \%$ produce with energy- or fibre-rich cereal grain products $(25 \%$ each) (variation 'produce'), or based on 50\% sugar beet pulp with compound feed and dehydrated lucerne pellets ( $25 \%$ each) (variation 'beet-pulp'). The non-forage portions had similar ME $\left(12.6 \pm 0.3 \mathrm{MJ} \cdot \mathrm{kg}^{-1} \mathrm{DM}\right)$ and $\mathrm{CP}\left(125 \pm 6.4 \mathrm{~g} \cdot \mathrm{kg}^{-1} \mathrm{DM}\right)$ content, but different aNDFom content with more aNDFom in 'beet pulp' $\left(399 \mathrm{~g} \cdot \mathrm{kg}^{-1} \mathrm{DM}\right)$ than in 'produce' $\left(204 \mathrm{~g} \cdot \mathrm{kg}^{-1} \mathrm{DM}\right)$. The animals were fed two major meals per day (8:00 and 16:00).

\section{Statistical analysis}

The analysis of variance, using the GLM procedure in SAS 9.3 (SAS Institute Inc., Cary, NC, USA), was conducted for multiple comparisons of feedstuff chemical composition and fermentation characteristics. Category of feed was the fixed effect in the model, and least squares means were compared using the Tukey's test (differences were considered significant at $P<0.05$ ). The Student's t-test was used in SAS 9.3 for a pairwise comparison of different GP from incubation with or without PEG (differences were significant at $P<0.05$ ).

\section{Results}

\section{Composition and fermentation of forage}

The highest ME contents were shown for lucerne hay, lucerne-grass mixture and further forage; however the ME contents for lucerne-grass mixture and other forage did not differ from browse leaves 
(Table 2). The highest CP contents were shown for other forage, lucerne hay, dried browse and lucernegrass mixture; however the $\mathrm{CP}$ content for other forage, dried browse and lucerne-grass mixture did not differ from browse leaves. In comparison to all other forages, browse bark had significantly lower contents of $\mathrm{ME}$ and $\mathrm{CP}$ and significantly higher contents of aNDFom, ADFom and $\mathrm{ADL}(P<0.001)$. A significantly greater content of $\mathrm{ME}(P=0.035)$ and CP $(P=0.002)$ and a significantly lower ADL content $(P=0.017)$ were estimated in lucerne hay when compared to browse leaves.

During fermentation (Table 2; Figure 1), gas was released with a rate ranging from $5.5 \% \cdot \mathrm{h}^{-1}$

Table 2. Contents of metabolizable energy (ME), crude protein (CP), ash, crude fat (CF) and fibre fractions, results for cumulative gas production at $2 \mathrm{~h}$ of incubation (GP2), maximal GP $(\mathrm{a}+\mathrm{b})$ and GP rate (c) (least squares means \pm standard error) and $\mathrm{R}^{2}$ of regression curves of forage

\begin{tabular}{lllllllcc}
\hline Indices & $\begin{array}{l}\text { Browse } \\
\text { leaves }\end{array}$ & $\begin{array}{l}\text { Browse } \\
\text { bark }\end{array}$ & $\begin{array}{l}\text { Dried } \\
\text { browse }\end{array}$ & $\begin{array}{l}\text { Lucerne } \\
\text { hay }\end{array}$ & $\begin{array}{l}\text { Lucerne- } \\
\text { grass mixture }\end{array}$ & $\begin{array}{l}\text { Other } \\
\text { forage }\end{array}$ & $\begin{array}{l}\text { Grass } \\
\text { hay }\end{array}$ & $\begin{array}{l}\text { Grass- } \\
\text { clover hay }^{*}\end{array}$ \\
\hline $\mathrm{ME}, \mathrm{MJ} \cdot \mathrm{kg}^{-1} \mathrm{DM}$ & $8.1 \pm 0.2^{\mathrm{b}}$ & $6.8 \pm 0.2^{\mathrm{c}}$ & $7.5 \pm 0.4^{\mathrm{abc}}$ & $8.9 \pm 0.2^{\mathrm{a}}$ & $9.2 \pm 0.4^{\mathrm{ab}}$ & $8.7 \pm 0.6^{\mathrm{ab}}$ & 7.1 & 9.8 \\
$\mathrm{CP}, \mathrm{g} \cdot \mathrm{kg}^{-1} \mathrm{DM}$ & $148 \pm 4.5^{\mathrm{b}}$ & $61.9 \pm 4.9^{\mathrm{c}}$ & $160 \pm 13^{\mathrm{ab}}$ & $179 \pm 6.6^{\mathrm{a}}$ & $148 \pm 13^{\mathrm{ab}}$ & $181 \pm 17^{\mathrm{ab}}$ & 90.0 & 119 \\
$\mathrm{Ash}, \mathrm{g} \cdot \mathrm{kg}^{-1} \mathrm{DM}$ & $73.5 \pm 3.7^{\mathrm{cd}}$ & $62.3 \pm 4.1^{\mathrm{d}}$ & $78.6 \pm 11^{\mathrm{bcd}}$ & $104 \pm 5.5^{\mathrm{b}}$ & $96.9 \pm 11^{\mathrm{abc}}$ & $148 \pm 14^{\mathrm{a}}$ & 43.3 & 94.6 \\
$\mathrm{CF}, \mathrm{g} \cdot \mathrm{kg}^{-1} \mathrm{DM}$ & $37.0 \pm 2.9$ & $26.9 \pm 3.2$ & $34.3 \pm 8.4$ & $25.7 \pm 4.3$ & $33.1 \pm 8.4$ & $23.0 \pm 11$ & 16.9 & 11.5 \\
$\mathrm{aNDFom}, \mathrm{g} \cdot \mathrm{kg}^{-1} \mathrm{DM}$ & $449 \pm 12^{\mathrm{b}}$ & $568 \pm 13^{\mathrm{a}}$ & $393 \pm 35^{\mathrm{b}}$ & $454 \pm 18^{\mathrm{b}}$ & $482 \pm 35^{\mathrm{ab}}$ & $373 \pm 45^{\mathrm{b}}$ & 720 & 486 \\
$\mathrm{ADFom}, \mathrm{g} \cdot \mathrm{kg}^{-1} \mathrm{DM}$ & $313 \pm 9.6^{\mathrm{b}}$ & $500 \pm 10^{\mathrm{a}}$ & $274 \pm 28^{\mathrm{b}}$ & $318 \pm 14^{\mathrm{b}}$ & $329 \pm 28^{\mathrm{b}}$ & $308 \pm 36^{\mathrm{b}}$ & 433 & 290 \\
$\mathrm{ADL}, \mathrm{g} \cdot \mathrm{kg}^{-1} \mathrm{DM}$ & $141 \pm 7.6^{\mathrm{b}}$ & $236 \pm 8.4^{\mathrm{a}}$ & $90.3 \pm 22^{\mathrm{bc}}$ & $95.6 \pm 11^{\mathrm{c}}$ & $75.1 \pm 22^{\mathrm{bc}}$ & $61.1 \pm 29^{\mathrm{bc}}$ & 76.0 & 51.5 \\
$\mathrm{GP} 2 \mathrm{ml} \cdot 200 \mathrm{~m} \mathrm{~g}^{-1} \mathrm{DM}$ & $9.9 \pm 0.3^{\mathrm{b}}$ & $7.0 \pm 0.3^{\mathrm{c}}$ & $8.6 \pm 0.9^{\mathrm{bc}}$ & $11.4 \pm 0.5^{\mathrm{ab}}$ & $13.0 \pm 0.9^{\mathrm{a}}$ & $10.4 \pm 1.2^{\mathrm{abc}}$ & 5.4 & 12.7 \\
$\mathrm{a}+\mathrm{b}, \mathrm{ml} \cdot 200 \mathrm{~m} \mathrm{~g}^{-1} \mathrm{DM}$ & $36.7 \pm 1.1^{\mathrm{bc}}$ & $32.2 \pm 1.2^{\mathrm{c}}$ & $38.6 \pm 3.1^{\mathrm{abc}}$ & $42.9 \pm 1.6^{\mathrm{a}}$ & $45.1 \pm 3.1^{\mathrm{ab}}$ & $40.4 \pm 4.0^{\mathrm{abc}}$ & 49.1 & 55.0 \\
$\mathrm{C}, \% \cdot \mathrm{h}^{-1}$ & $6.1 \pm 0.3^{\mathrm{b}}$ & $7.6 \pm 0.4^{\mathrm{a}}$ & $5.5 \pm 1.0^{\mathrm{ab}}$ & $8.3 \pm 0.5^{\mathrm{a}}$ & $6.5 \pm 1.0^{\mathrm{ab}}$ & $9.2 \pm 1.3^{\mathrm{ab}}$ & 3.0 & 7.2 \\
$\mathrm{R}^{2}$ of the GP model, \% & 64.5 & 59.5 & 86.0 & 96.2 & 88.9 & 89.0 & 99.7 & 99.7 \\
\hline
\end{tabular}

aNDFom - neutral detergent fibre, assayed with heat stable amylase, expressed exclusive of residual ash; ADFom - acid detergent fibre, expressed exclusive of residual ash; $\mathrm{ADL}$ - acid detergent lignin; DM - dry matter; *excluded from statistical analyses (single samples only); ${ }^{a-d}-$ means with different superscripts within rows are significantly different at $P<0.05$

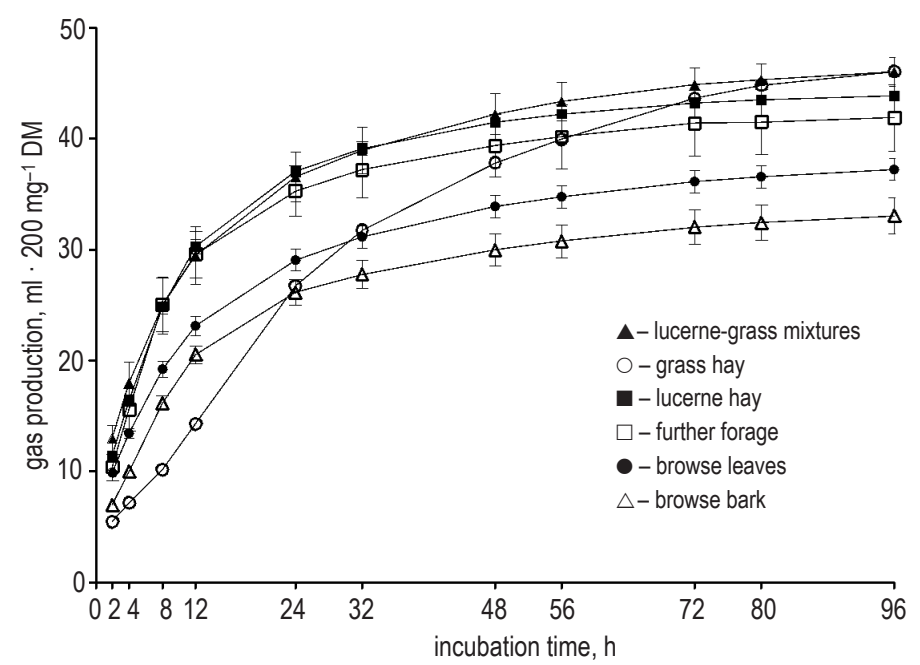

Figure 1. Fermentation pattern of forage over $96 \mathrm{~h}$ of incubation in the Hohenheim gas test (mean \pm standard error); values represent mean of gas production from incubation of browse leaves and browse bark with and without polyethylene glycol (PEG) supplementation

Table 3. Cumulative gas production (GP) at $2 \mathrm{~h}$ of incubation (GP2; $\left.\mathrm{ml} \cdot 200 \mathrm{mg}^{-1} \mathrm{DM}\right)$, maximal GP $\left(\mathrm{a}+\mathrm{b} ; \mathrm{ml} \cdot 200 \mathrm{mg}^{-1} \mathrm{DM}\right)$ and GP rate $\left(\mathrm{c} ; \% \cdot h^{-1}\right)$ for browse leaves, browse bark and dried browse after incubation with or without polyethylene glycol (PEG)

\begin{tabular}{|c|c|c|c|c|c|c|}
\hline Indices & Browse leaves & Increase & Browse bark & Increase & Dried browse & Increase \\
\hline GP2 & $8.8 \pm 2.2$ & \multirow{2}{*}{$23 \%{ }^{*}$} & $5.8 \pm 2.1$ & \multirow{2}{*}{$38 \%{ }^{*}$} & $8.0 \pm 2.9$ & \multirow{2}{*}{$15 \%$ *** } \\
\hline GP2 with PEG & $10.9 \pm 2.2$ & & $8.0 \pm 1.8$ & & $9.2 \pm 2.8$ & \\
\hline$a+b$ & $34.9 \pm 7.2$ & \multirow{2}{*}{$10 \% *$} & $30.3 \pm 9.6$ & \multirow{2}{*}{$13 \%{ }^{*}$} & $36.8 \pm 5.1$ & \multirow{2}{*}{$13 \%{ }^{* *}$} \\
\hline$a+b$ with PEG & $38.4 \pm 6.1$ & & $34.0 \pm 9.9$ & & $40.4 \pm 4.5$ & \\
\hline c & $5.2 \pm 1.9$ & \multirow{2}{*}{$32 \%{ }^{*}$} & $6.2 \pm 2.1$ & \multirow{2}{*}{$43 \%{ }^{*}$} & $4.7 \pm 0.7$ & \multirow{2}{*}{$36 \%$ ** } \\
\hline$c$ with PEG & $6.9 \pm 1.9$ & & $9.0 \pm 4.1$ & & $6.3 \pm 0.4$ & \\
\hline
\end{tabular}

DM - dry matter; data presented as mean \pm standard deviation; significant increase is labelled with * $(P<0.0001),{ }^{* *}(0.01 \geq P>0.0001)$ or ${ }^{* * *}(0.05 \geq P>0.01)$ 


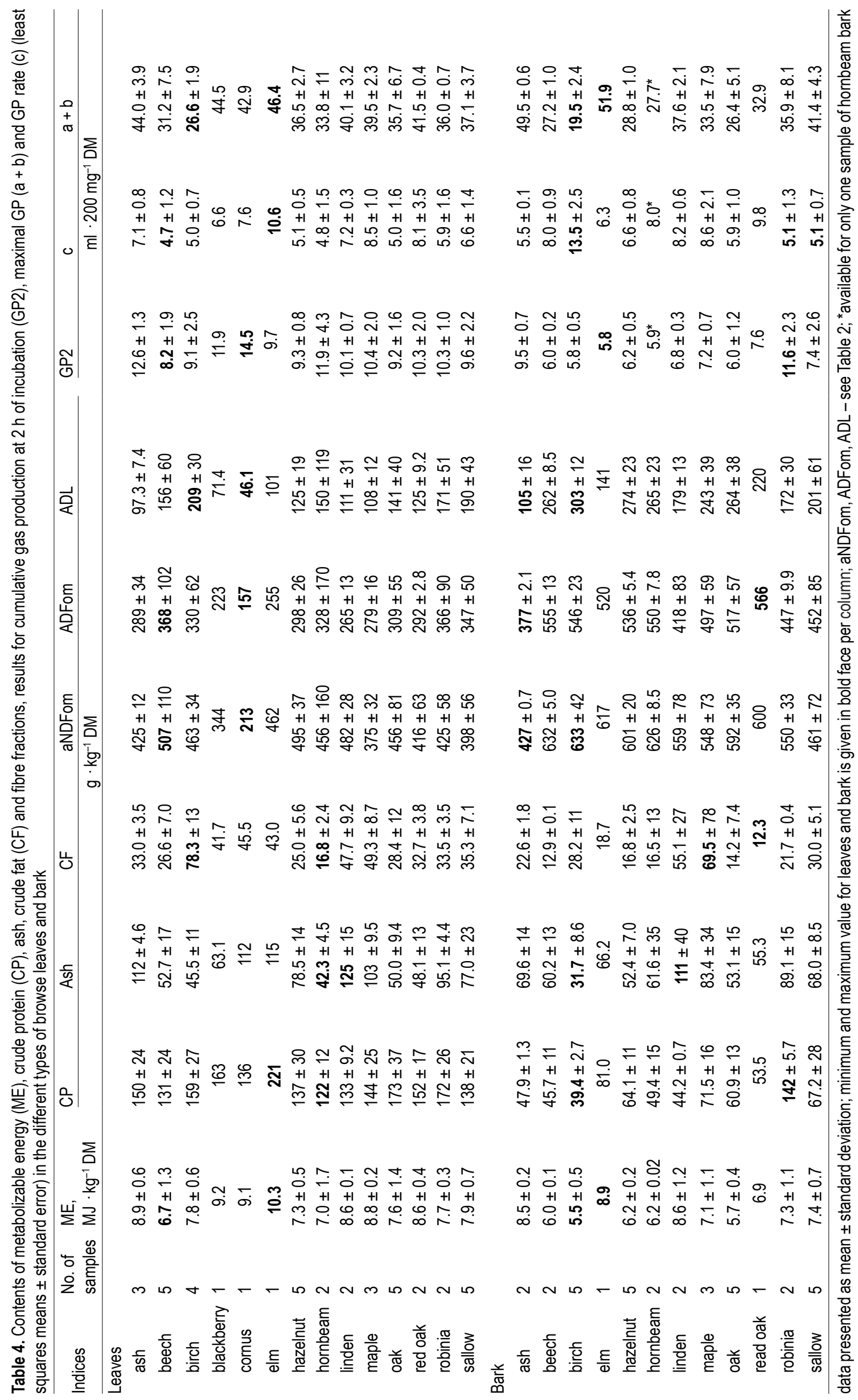




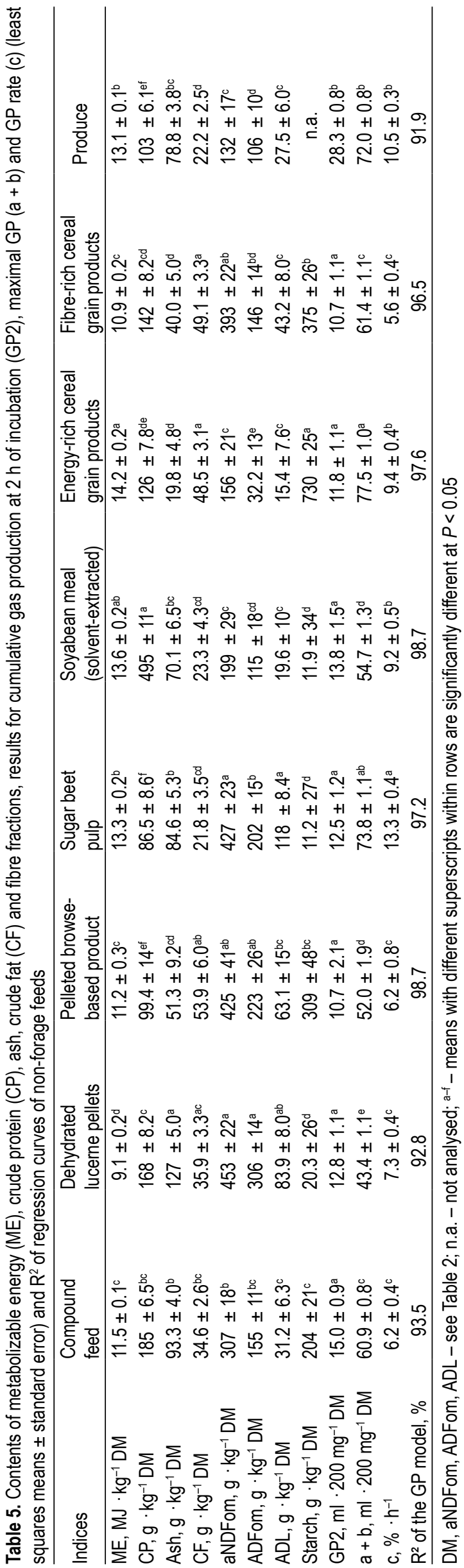

(dried browse) to $9.2 \% \cdot \mathrm{h}^{-1}$ (other forage). The GP2 and maximal GP in browse bark were significantly lower when compared to lucerne hay and lucernegrass mixture $(P<0.001)$. Lucerne hay differed significantly from browse leaves when it comes to GP rate $(P=0.004)$ and maximal GP $(P=0.023)$. Estimation of GP parameters was particularly weak in browse leaves and browse bark (Table 2; Figure 1). PEG supplementation led to a significantly higher GP2, maximal GP and GP rate in browse (Table 3).

The type of browse leaves (Table 4) showed an effect on contents of ME $(P=0.026), \mathrm{CF}(P<0.001)$, ash $(P<0.001)$ and $\mathrm{ADL}(P=0.021)$, GP rate $(P=0.002)$ and maximal GP $(P=0.005)$. Regarding samples of bark, the type of browse had a significant effect on chemical composition (the weakest $P=0.007$ ) and fermentation (the weakest $P=0.004$ ).

\section{Composition and fermentation of non-forage feeds}

The lowest content of ME in non-forage feeds (Table 5) was measured in dehydrated lucerne pellets $(P<0.001)$, whereas in energy-rich cereal grain products ME content was the highest $(P=0.012$; except compared to soyabean meal). Sugar beet pulp, produce and the pelleted browse-based product showed comparably low CP contents; however CP content for pelleted browse-based product did not differ from energy-rich cereal grain products. The overall highest $\mathrm{CP}$ content was found for soyabean meal $(P<0.001)$. Regarding fibre fractions, the lowest contents of aNDFom were shown in soyabean meal, produce and energy-rich cereal grain products; in the latter it was also the lowest overall content of $\operatorname{ADFom}(P=0.009)$. The highest values for aNDFom were measured in dehydrated lucerne pellets, pelleted browse-based product, sugar beet pulp and fibre-rich cereal grain products; the highest ADFom was shown in dehydrated lucerne pellets and pelleted browse-based product. Dehydrated lucerne pellets and sugar beet pulp contained the most ADL, whereas the other non-forage feeds showed ADL contents of similarly low levels.

Regarding fermentation (Table 5; Figure 2), the highest GP2 was shown in produce $(P<0.001)$. High-energy cereal grain products and sugar beet pulp showed the highest maximal GP; however the maximal GP for sugar beet pulp did not differ from produce, whereas it was the lowest in dehydrated lucerne pellets $(P<0.001)$. The highest GP rate was estimated in sugar beet pulp $(P<0.001)$, whereas lower GP rates were indicated in compound feed, dehydrated lucerne pellets, pelleted browse-based product and fibre-rich cereal grain products. 


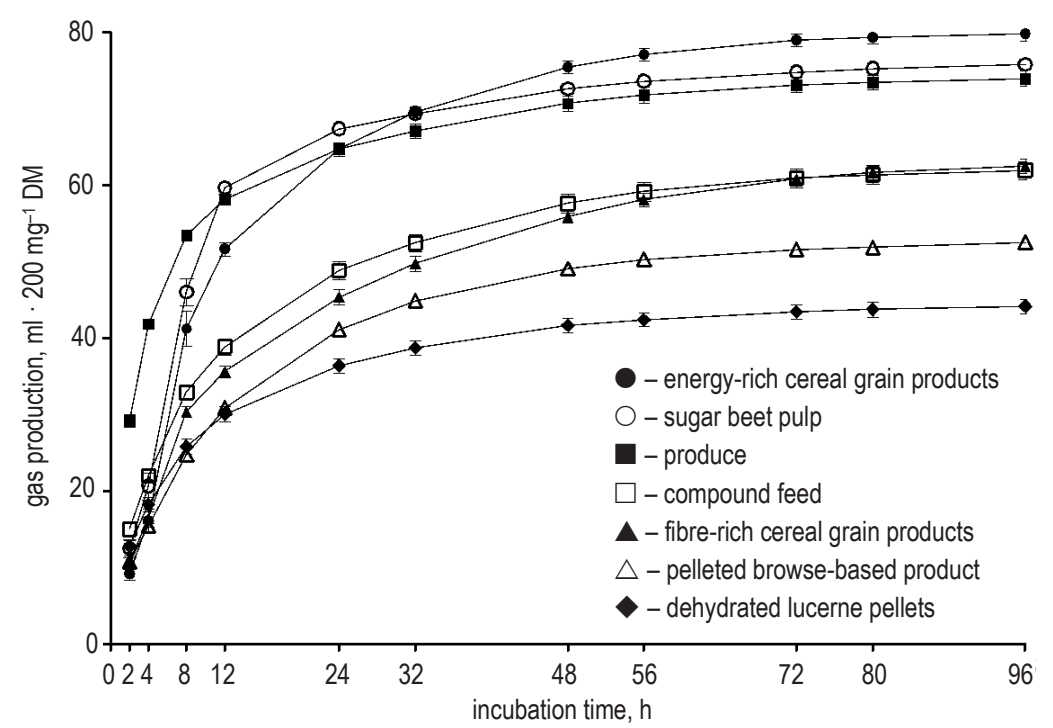

Figure 2. Fermentation pattern of non-forage feeds over $96 \mathrm{~h}$ of incubation in the Hohenheim gas test (mean \pm standard error)

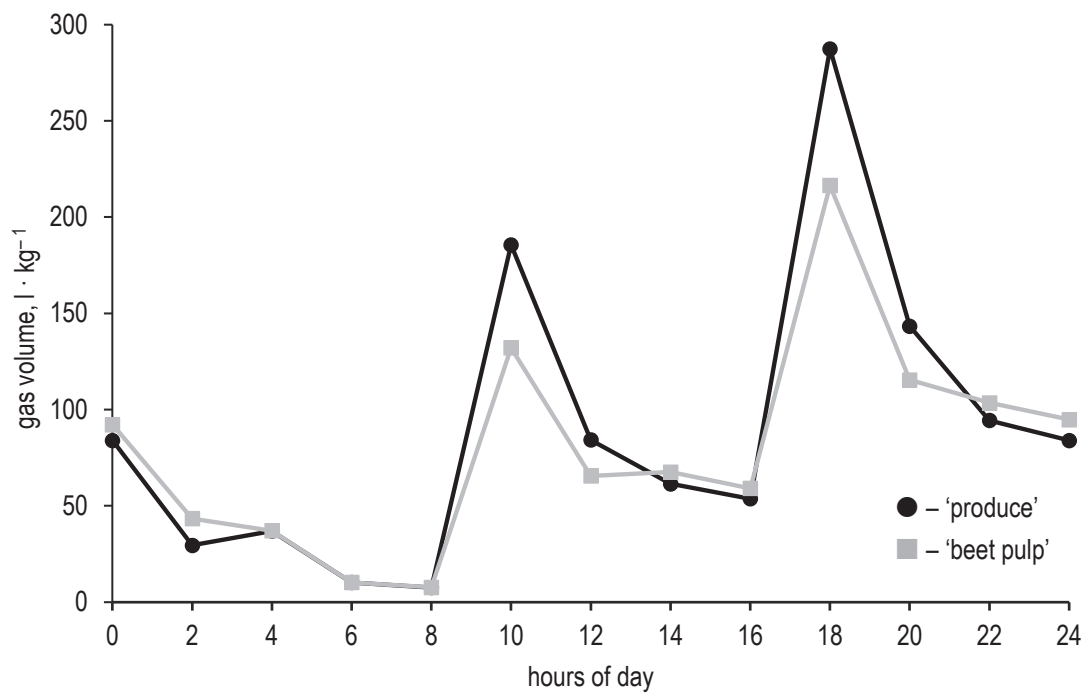

Figure 3. Theoretical course of gas production over $24 \mathrm{~h}$ when feeding $5 \mathrm{~kg}$ of non-forage portion (DM) 'produce' ( $50 \%$ produce, $25 \%$ energy-rich cereal grain products, $25 \%$ fibre-rich cereal grain products) or 'beet pulp' ( $50 \%$ sugar beet pulp, $25 \%$ compound feed, $25 \%$ deydrated lucerne pellets)

Regarding the theoretical distribution of GP (Figure 3), stronger peaks ( $+29 \%$ in the morning, $+25 \%$ in the afternoon) occurred two hours after intake of ration variation 'produce' and overall GP was higher $(+12 \%)$.

\section{Discussion}

\section{Evaluation and quality of forage}

Quality of lucerne hay. Lucerne hay was used as main forage in the study. Unfortunately, the information on its maturity was not available; according to NRC (2001) it could correspond to legume hay of mid maturity $\left(400-460 \mathrm{~g} \mathrm{NDF} \cdot \mathrm{kg}^{-1} \mathrm{DM}\right)$. In accordance with ruminant feed values estimated by Universität Hohenheim - Dokumentationsstelle (1997), lucerne hay was of good quality (proper contents of ME, CP, ash and CF) and so constituted a stable source of fibre. In the literature on fibre fractions it was noticed that analytical methods for NDF and ADF were not consistently done and/or stated regarding $\alpha$-amylase treatment, ash correction and sequential analysis. Therefore, a higher consensus on nomenclature and methods in analysis of fibre is desirable.

Lucerne hay vs browse. Besides high intake and availability, the suitability of lucerne hay as forage for giraffes in captivity is connected with its similar chemical composition compared to browse. However, within the presently selected forages lucerne hay was significantly different from browse 
leaves when it comes to the content of $\mathrm{ME}(+9 \%$ in lucerne hay), CP (+17\% in lucerne hay) and ADL ( $-47 \%$ in lucerne hay). Furthermore higher maximal GP $(+17 \%)$ and GP rate $(+36 \%)$ were detected in lucerne hay. As the present browse samples were of temperate type, information on the chemical composition and fermentation of native Acacia sp. (Abdulrazak, 2000; Rubanza et al., 2005) was added to considerations (Table 6). The aNDFom and ADFom content of lucerne hay was similar to the temperate browse leaves. In addition, ADL content in temperate browse leaves was similar to Acacia sp. For CP content, lucerne hay matched better with Acacia sp. which was also true for maximum GP, but not for GP rate which was higher in lucerne hay than in temperate or indigenous browse. Finally some conformity to temperate and indigenous browse underlined the status of lucerne hay as good alternative forage. Nevertheless the suitability may not be fully confirmable based on similarities either to Acacia sp. or temperate browse as the species showed differences among themselves.

Quality of temperate browse as forage. The evaluation of fresh browse as inherent part of rations for giraffes is challenging. The chemical composition of browse samples collected in the study varied considerably. It may also explain the weakness of curve fitting in case of leaves and bark compared to the other feeds. The quality of leaves was less influenced by the type of browse than the quality of bark. Especially CP and fibre contents were more stable in leaves indicating a greater nutritional consistence. Load of hardly or indigestible cell wall components from bark was high, whereas $\mathrm{CP}$ and ME contents were correspondingly low. In the observed giraffe facilities leafy branches and trees were usually barkstripped and intake of browse material from freshly cut branches and trees during winter was even

Table 6. Contents of metabolizable energy (ME), crude protein (CP) and fibre fractions, maximal gas production (GP) $(a+b)$ and GP rate (c) of browse leaves, browse bark and lucerne hay as presently analysed in comparison to literature data for Acacia sp.

\begin{tabular}{lcccc}
\hline Indices & $\begin{array}{c}\text { Browse } \\
\text { leaves }\end{array}$ & $\begin{array}{l}\text { Browse } \\
\text { bark }\end{array}$ & $\begin{array}{l}\text { Lucerne } \\
\text { hay }\end{array}$ & $\begin{array}{l}\text { Acacia } \\
\text { sp. }{ }^{1}\end{array}$ \\
\hline $\mathrm{ME}, \mathrm{MJ} \cdot \mathrm{kg}^{-1} \mathrm{DM}$ & 7.9 & 6.7 & 8.9 & 7.4 \\
$\mathrm{CP}, \mathrm{g} \cdot \mathrm{kg}^{-1} \mathrm{DM}$ & 148 & 61.9 & 179 & 182 \\
aNDFom, $\mathrm{g} \cdot \mathrm{kg}^{-1} \mathrm{DM}$ & 449 & 568 & 454 & $362^{2}$ \\
$\mathrm{ADFom}, \mathrm{g} \cdot \mathrm{kg}^{-1} \mathrm{DM}$ & 313 & 501 & 318 & 261 \\
$\mathrm{ADL}, \mathrm{g} \cdot \mathrm{kg}^{-1} \mathrm{DM}$ & 141 & 236 & 95.7 & 117 \\
$\mathrm{a}+\mathrm{b}, \mathrm{ml} \cdot 200 \mathrm{mg}^{-1} \mathrm{DM}$ & 34.9 & 30.3 & 42.9 & 37.1 \\
$\mathrm{c}, \% \cdot \mathrm{h}^{-1}$ & 5.2 & 6.3 & 8.3 & 4.4 \\
\hline
\end{tabular}

aNDFom, ADFom, ADL, DM - see Table 2; ${ }^{1}$ according to Abdulrazak et al., 2000; Rubanza et al., 2005; ' 2 given as NDFom
Table 7. Share of browse portions (\%) in total intake of dry matter $(\mathrm{DM})$, metabolizable energy (ME) and nutrients as consumed during documentation periods in giraffe facilities of twelve German zoos

\begin{tabular}{|c|c|c|c|c|c|c|c|}
\hline Period & Season & $\mathrm{DM}$ & ME & $\mathrm{CP}$ & aNDFom & ADFom & $\mathrm{ADL}$ \\
\hline 1 & Winter & 2.8 & 1.3 & 0.8 & 4.3 & 3.7 & 4.0 \\
\hline 2 & Winter & 9.0 & 6.8 & 6.2 & 8.6 & 11.7 & 13.7 \\
\hline 3 & Winter & 2.6 & 2.2 & 2.5 & 2.4 & 2.6 & 2.5 \\
\hline 4 & Winter & 4.8 & 3.6 & 3.4 & 530 & 6.2 & 14.1 \\
\hline 5 & Winter & 4.3 & 3.5 & 4.6 & 4.9 & 4.9 & 5.3 \\
\hline 6 & Summer & 11.3 & 7.2 & 8.8 & 15.0 & 18.8 & 28.5 \\
\hline 7 & Summer & 1.2 & 0.8 & 1.1 & 1.4 & 1.3 & 1.9 \\
\hline 8 & Summer & 12.1 & 10.7 & 10.6 & 12.0 & 13.3 & 19.8 \\
\hline 9 & Summer & 1.7 & 1.3 & 1.3 & 2.0 & 2.2 & 2.2 \\
\hline 10 & Summer & 13.1 & 9.4 & 11.3 & 15.2 & 17.2 & 23.5 \\
\hline 11 & Summer & 10.3 & 7.2 & 7.4 & 12.8 & 17.3 & 28.1 \\
\hline 12 & Summer & 2.4 & 2.1 & 2.3 & 2.4 & 2.7 & 4.7 \\
\hline 13 & Summer & 9.2 & 7.8 & 6.6 & 9.2 & 11.7 & 17.0 \\
\hline 14 & Summer & 5.2 & 4.6 & 5.7 & 7.1 & 7.4 & 10.5 \\
\hline 15 & Summer & 11.1 & 6.7 & 7.2 & 14.2 & 16.4 & 24.4 \\
\hline 16 & Summer & 12.4 & 9.2 & 9.9 & 14.2 & 15.4 & 22.9 \\
\hline 17 & Summer & 5.5 & 4.7 & 4.1 & 5.3 & 5.5 & 7.7 \\
\hline
\end{tabular}

CP, aNDFom, ADFom, ADL - see Table 2

reduced to woody material. Consequently, browse DM intake consisted of approximately $20 \%$ bark DM intake ( $1 \%$ of total DM intake). In contrast, in free-ranging giraffes the rumen ingesta consist of $15 \%$ woody plant material (Owen-Smith, 1988), so the determined amounts of ingested bark would indicate the low risk of dietary inconsistency. In result, the overall dietary contribution of browse was reduced to $0-13 \%$ of dietary DM (Table 7). As zoo rations contain considerable amounts of high-protein forage and energy-rich concentrates (Hummel et al., 2006b), it was more relevant to deliver the fibre from browse than supply animals with energy and protein.

Browse contain high amounts of secondary plant compounds like tannins (Rubanza et al., 2005). Browsers are adapted to them by secretion of tanninbinding salivary proteins (Robbins et al., 1987; Austin et al., 1989). Tannin-binding proteins were lacking under respective in vitro conditions. Rumen fluid needed to be taken from sheep as grazing ruminants, which do not produce any tannin-binding substances even if tannin-containing diets are fed (Austin et al., 1989). Consequently, it appeared debatable how accurate GP of tannin-containing forage was simulated for a browsing ruminant. The effectivity of in vivo tannin-inhibition is far more complex (Elahi et al., 2012), and a pure quantitative analysis of phenolic contents lacks validity. In contrast, the incubation of tannin-containing forage with PEG as tannin-binding substance is capable to mitigate the 
adverse effects of tannins on fermentation and the percentage increase in gas volume correlates with the tannin content (Makkar et al., 1995). Consequently, the use of PEG as substitute for tannin-specific proteins during in vitro fermentation was valued as the most reliable way to consider peculiarities during in vivo fermentation of browse in browsers. However, it should be considered that the extent of transferability of effects of PEG or tanninbinding salivary proteins on fermentation remains changeable. Measuring GP with and without PEG supplementation was an attempt to prevent underor overestimated potential effects of PEG and as a consequence to evaluate as thoroughly as possible the fermentation of tannin-containing forage.

\section{Evaluation and quality of non-forage feeds}

Insufficient energy and nutrient supply for giraffes in captivity resulted in their poor body condition and fat atrophy (Hummel and Clauss, 2006). In captivity, grinding and pelleting of forage increase its density and result in a higher intake and more rapid passage of insoluble matter (Van Soest, 1994). Examined dehydrated lucerne pellets were totally consistent with the chemical composition and fermentation pattern of lucerne hay and offered supplementation of additional fermentable fibre and CP. Additional completing of diets was possible with feeds of higher energy content. As concentrate feeders or total mixed rations are irrelevant in practical giraffe nutrition, the intake of non-forage feedstuffs occur very few times a day. Therefore an even fermentation of non-forage feedstuffs is highly desirable. Present compound feeds were moderate in the nutrient composition and fermentation. A similar GP rate compared to browse leaves indicated GP with comparable uniformity. Presently used high-energy feeds delivered energy from different ingredients. Produce include high amounts of soluble nonstructural carbohydrate (i.e. sugar) as energy source (Van Soest et al., 1991). Energy, in energy-rich cereal grain products, is mainly provided by starch which belongs also to the nonstructural carbohydrates, but shows more ambiguous solubility (Van Soest et al., 1991). Much of the energy in sugar beet pulp is based on pectins, an easily fermentable constituent of the cell wall (Van Soest et al., 1991; Van Soest, 1994) representing approximately $19-25 \%$ of DM in beet pulp (Phatak et al., 1988). Although the maximal GP was similar among the high-energy feeds, only produce generated an immediate short time GP (Figure 4). In contrast, short time fermentation in energy-rich cereal grain products and sugar beet pulp was delayed, thus GP happened in similar but less 'explosive' rates (Oftedal et al., 1996). Accordingly, the theoretical additive distribution of GP over $24 \mathrm{~h}$ was characterized with stronger peaks immediately after intake of variation 'produce' (Figure 3). Differences between starch and pectin fermentation occur because for the acid load. The risk of acidosis induction and a potential switch from acetate to lactate production during fermentation is higher for starch (Van Soest et al., 1991; Odongo et al., 2006). In contrast, the structure of galacturonic acid in pectins provides buffering potential through cation exchange capacity and metal ion binding (Van Soest et al., 1991). An exchange of grains with beet pulp resulted in a significant increase of rumen $\mathrm{pH}$ and acetate concentration in cows (Mahjoubi et al., 2009). Presently, a theoretical replacement of non-forage portion 'produce' with 'beet pulp' led to an overall lower GP without less energy or protein content in the non-forage proportion, but with provision of additional aNDFom. Ultimately the interest of providing suitable non-forage feeds with the least negative impact on rumen fermentation increases with high inclusion levels of non-forage feeds. In general energy concentrates put higher pressure on rumen $\mathrm{pH}$ than forage, so the sugar beet pulp, being a high-energy feed, has the most preferable features to maintain rumen conditions balanced.

\section{Protein supplementation}

Sufficient CP supply with ad libitum provision of lucerne hay may work with higher certainty than widely expected for giraffes in captivity. The CP content in the present lucerne hay was higher and CP precipitation from tannins and fibre-binding from lignification was expected to be absent or much lower than in browse. In zoo studies, CP intake was mostly sufficient to cover estimated requirements or rather reach values given from free-range studies (e.g., Pellew, 1984; Baer et al., 1985; Hatt et al., 2005). Nevertheless feeds high in CP were used in addition. To try a new perspective, the term ruminal nitrogen balance (RNB) of the German protein evaluation system for dairy cows (GfE, 2001) was introduced. This term is used to evaluate nitrogen supply to ruminal microbes and optimize protein use efficiency. It compares ruminal input ( $\mathrm{N}$ in diet) and output (ruminal outflow of microbial and undegraded $\mathrm{N}$ ). Lack of ruminal $\mathrm{N}$ (negative RNB) may retard fermentation and microbial synthesis; an overspill (positive RNB) leads to high urinary $\mathrm{N}$ excretion and less effective protein utilization. Feeds should be combined as to result in a RNB close to zero (GfE, 2001). RNB input of $+8 \mathrm{~g} \cdot \mathrm{kg}^{-1} \mathrm{DM}$ is present in comparable CP content 


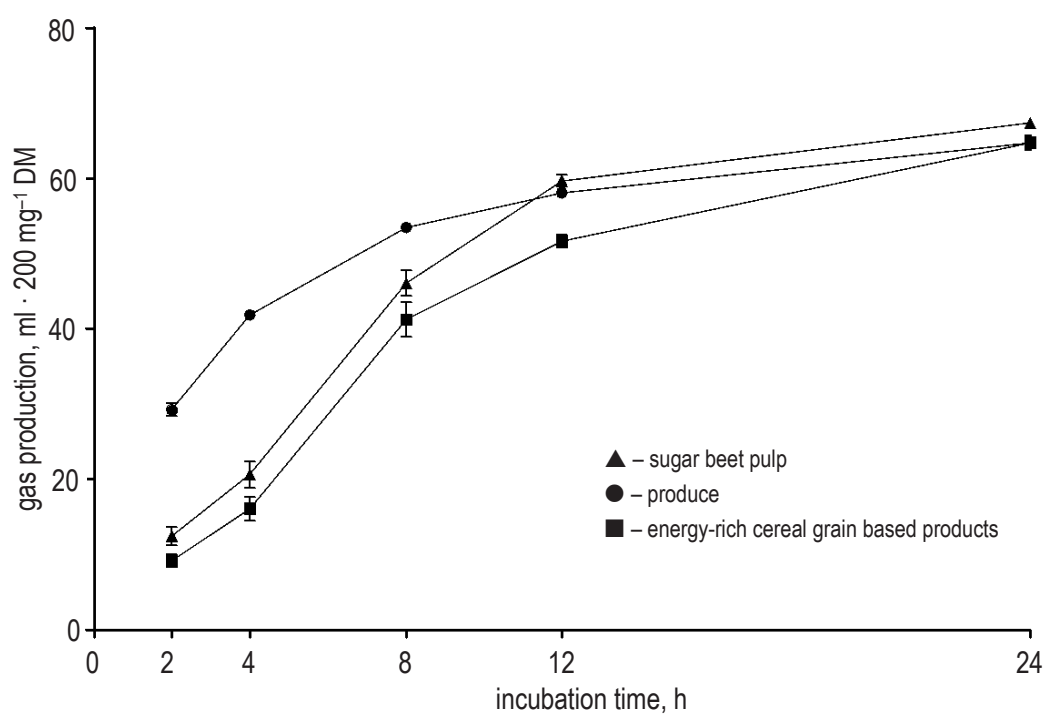

Figure 4. Pattern of gas production of energy providing feedstuffs at 2, 4, 8, 12 and $24 \mathrm{~h}$ of incubation in the Hohenheim gas test (mean \pm standard error)

in lucerne hay (LfL, 2015). This is a reason to query whether the RNB in giraffes in captivity changes to positive values with lucerne hay being supplied as major diet component. Consequently there was no need to provide non-forage feeds for the purpose of protein supply. Any negative compensation to the RNB would have been delivered only with high-energy non-forage feeds, with sugar beet pulp permitting energy with the least additional supply of CP.

\section{Conclusions}

Analyses of forage fed in twelve German giraffe facilities showed that lucerne hay was of stable quality, and chemical composition and fermentation were generally similar to browse. Therefore lucerne hay presented a good agreement due to similarities to browse and the high acceptance in giraffes. Temperate browse showed a large variation of qualities according to type, and supplementation of polyethylene glycol (PEG) 6000 as tannin-binding agent led to a greater in vitro gas production (GP). Dehydrated lucerne pellets largely resembled lucerne hay and compound feeds showed a desirable overall 'middlingness' regarding composition and fermentation. The suitability of sugar beet pulp was obvious from smooth fermentation and lower ruminal acid load as compared to sugar- or starch-based products. So, suitable recommendations on feedstuffs for giraffes in captivity were confirmed. However, the protein value of proper quality lucerne hay, provided for ad libitum intake, should not be underrated in the composing of non-forage feedstuff portions.

\section{Acknowledgement}

The authors would like to thank the staff of all participating zoos for their interest and effort in the study. Additional thanks are directed to the laboratory staff of the Animal Nutrition Group, University of Bonn, and all colleagues that gave us a helping hand. The first author (I.G.) was awarded a scholarship by Evangelisches Studienwerk Villigst e.V. (Schwerte, Germany). Additional financial support was provided by Gesellschaft der Freunde der Agrar- und Ernährungswissenschaftlichen Fakultät der Christian-Albrechts-Universität zu Kiel e.V., Bonner Förderkreis Tierernährung e.V. and fonds allocated to the Institute of Animal Science, University of Bonn.

\section{References}

Abdulrazak S.A., Fujihara T., Ondiek J.K., Ørskov E.R., 2000. Nutritive evaluation of some Acacia tree leaves from Kenya. Anim. Feed Sci. Tech. 85, 89-98

Austin P.J., Suchar L.A., Robbins C.T., Hagerman A.E., 1989. Tanninbinding proteins in saliva of deer and their absence in saliva of sheep and cattle. J. Chem. Ecol. 15, 1335-1347

Baer D.J., Oftedal O.T., Fahey Jr. G.C., 1985. Feed selection and digestibility by captive giraffes. Zoo Biol. 4, 57-64

Brandt M., Schuldt A., Mannerkorpi P., Vearasilp T., 1987. Zur enzymatischen Stärkebestimmung im Darminhalt und Kot von Kühen mit hitzestabiler Amylase. Arch. Anim. Nutr. 37, 455 (Abstr.)

Elahi M.Y., Rouzbehan Y., Rezaee A., 2012. Effects of phenolic compounds in three oak species on in vitro gas production using inoculums of two breeds of indigenous Iranian goats. Anim. Feed Sci. Tech. 176, 26-31

GfE, 2001. Empfehlungen zur Energie- und Nährstoffversorgung der Milchkühe und Aufzuchtrinder. DLG-Verlag. Frankfurt am Main (Germany), pp. 136 
GfE, 2008. New equations for predicting metabolisable energy of grass and maize products for ruminants. Proc. Soc. Nutr. Physiol. 17, 191-198

GfE, 2009. New equations for predicting metabolisable energy of compound feeds for cattle. Proc. Soc. Nutr. Physiol. 18, 143-146

Hatt J.-M., Schaub D., Wanner M., Wettstein H.-R., Flach E.J., Tack C., Hässig M., Ortmann S., Hummel J., Clauss M., 2005. Energy and fibre intake in a group of captive giraffe (Giraffa camelopardalis) offered increasing amounts of browse. J. Vet. Med. Ser. A 52, 485-490

Hummel J., Clauss M., 2006. Feeding. In: Z. Barta, M. Clauss, L. Culik, M. Damen, J. Hummel, G. Schleussner, K. Tomasova, W. Zimmermann (Editors). EAZA Husbandry and Management Guidelines for Giraffa camelopardalis. Burgers Zoo. Arnhem (the Netherlands), pp. 29-61

Hummel J., Nogge G., Clauss M., Nørgaard C., Johanson K., Nijboer J., Pfeffer E., 2006a. Energy supply of the okapi in captivity: Fermentation characteristics of feedstuffs. Zoo Biol. 25, 251-266

Hummel J., Zimmermann W., Langenhorst T., Schleussner G., Damen M., Clauss M., 2006b. Giraffe husbandry and feeding practices in Europe. Results of an EEP survey. Proc. Eur. Assoc. Zoo Wild. Vet. Conf. 6, 71-74

Lagowski J.M., Sell H.M., Huffman C.F., Duncan C.W., 1958. The carbohydrates in alfalfa Medicago sativa. I. General composition, identification of a nonreducing sugar and investigation of the pectic substances. Arch. Biochem. Biophys. 76, 303-316

LfL, 2015. Gruber Tabelle zur Fütterung der Milchkühe, Zuchtrinder, Schafe, Ziegen. 37. unveränderte Auflage. Kastner AG. Wolznach (Germany), pp. 94

Losand B., Alert H.-J., Arrigo Y. et al., 2014. Energiebestimmung von Grobfuttermitteln aus kleinkörnigen Leguminosen. VDLUFASchriftenr. 69, 761-769

Mahjoubi E., Amanlou H., Zahmatkesh M., Ghelich Khan M., Aghaziarati N., 2009. Use of beet pulp as a replacement for barley grain to manage condition score in over-conditioned late lactation cows. Anim. Feed Sci. Tech. 153, 60-67

Makkar H.P.S., Blümmel M., Becker K., 1995. Formation of complexes between polyvinyl pyrrolidones or polyethylene glycols and tannins, and their implication in gas production and true digestibility in in vitro techniques. Brit. J. Nutr. 73, 897-913

Menke K.-H., Steingass H., 1988. Estimation of the energetic feed value obtained from chemical analysis and in vitro gas production using rumen fluid. Anim. Res. Dev. 28, 7-55

NRC, 2001. Nutrient Requirements of Dairy Cattle. $7^{\text {th }}$ revised Edition. National Academies Press. Washington, DC

Odongo N.E., Valdes E.V., McBride B.W., 2006. Technical Note: Acidogenicity value and rumen acid load of common zoo animal feeds. Prof. Anim. Sci. 22, 194-199
Oftedal O.T., Baer D.J., Allen M.E., 1996. The feeding and nutrition of herbivores. In: D.G. Kleiman (Editor). Wild Mammals in Captivity: Principles and Techniques. University of Chicago Press. Chicago, IL (USA), pp. 129-138

Ørskov E.R., McDonald I., 1979. The estimation of protein degradability in the rumen from incubation measurements weighted according to rate of passage. J. Agr. Sci. 92, 499-503

Owen-Smith R.N., 1988. Megaherbivores: The Influence of Very Large Body Size on Ecology. Cambridge University Press. Cambridge (UK), pp. 369

Pellew R.A., 1984. Food consumption and energy budgets of the giraffe. J. Appl. Ecol. 21, 141-159

Phatak L., Chang K.C., Brown G., 1988. Isolation and characterization of pectin in sugar beet pulp. J. Food Sci. 53, 830-833

Robbins C.T., Moen A.N., 1975. Composition and digestibility of several deciduous browses in the Northeast. J. Wildlife Manage. $39,337-341$

Robbins C.T., Mole S., Hagerman A.E., Hanley T.A., 1987. Role of tannins in defending plants against ruminants: Reduction in dry matter digestion? Ecology 68, 1606-1615

Rubanza C.D.K., Shem M.N., Otsyina R., Bakengesa S.S., Ichinohe T., Fujihara T., 2005. Polyphenolics and tannins effect on in vitro digestibility of selected Acacia species leaves. Anim. Feed Sci. Tech. 119, 129-142

Steuer P., Südekum K.-H., Tütken T., Müller D.W.H., Kaandorp J., Bucher M., Clauss M., Hummel J., 2014. Does body mass convey a digestive advantage for large herbivores? Funct. Ecol. 28, 1127-1134

Thornton R.F., Minson D.J., 1973. The relationship between apparent retention time in the rumen, voluntary feed intake, and apparent digestibility of legume and grass diets in sheep. Aust. J. Agr. Res. 24, 889-898

Universität Hohenheim - Dokumentationsstelle, 1997. DLG-Futterwerttabellen für Wiederkäuer. $7^{\text {th }}$ Edition. DLG-Verlag. Frankfurt am Main (Germany), pp. 112

Van Soest P.J., 1988. A comparison of grazing and browsing ruminants in the use of feed resources. In: E.F. Thomson, F.S. Thomson (Editors). Increasing Small Ruminant Productivity in Semi-Arid Areas. ICARDA. Aleppo (Syria), pp. 67-79

Van Soest P.J., 1994. Nutritional Ecology of the Ruminant. $2^{\text {nd }}$ Edition. Cornell University Press. Ithaca, NY (USA), pp. 374

Van Soest P.J., Robertson J.B., Lewis B.A., 1991. Methods for dietary fiber, neutral detergent fiber, and nonstarch polysaccharides in relation to animal nutrition. J. Dairy Sci. 74, 3583-3597

VDLUFA, 2012. VDLUFA-Methodenbuch Bd. III, Die chemische Untersuchung von Futtermitteln. 8. Erg. VDLUFA-Verlag. Darmstadt (Germany) 